\title{
The Influence of Interest Groups on State Legislative Behavior
}

\author{
Shannon Jenkins
}

Research shows the influence of campaign contributions on congressional behavior is infrequent, but more pronounced in certain situations and for certain types of legislators. But it is unclear if these theories apply at the state level. This study examines the impact of campaign contributions in three state legislatures; results show group contributions impact roll call voting in a significant minority of cases and significant relationships are more likely for business and labor contributions, as at the national level. However, the analysis also shows there is variation in the pattern of influence across the states, which is not related to issue salience in all states.

Research examining the influence of interest groups over legislative behavior has often focused on the impact of contributions on roll call votes. Much of this research stems from normative concerns about the influence of groups on the political process. Many journalists and observers of the political system, along with the American public, believe that large contributions from interest groups must have some impact on roll call votes. They feel that interest groups play too large of a role in influencing voting and that such influence tends to undermine the democratic process. However, political scientists examining the impact of campaign contributions over roll call voting at the national level have generally found that the impact of such contributions is typically far less than alarmists might lead some to believe. Generally speaking, they find that campaign contributions tend to reinforce legislators' voting tendencies rather than change them although contributions do influence voting in about a quarter of the cases (Roscoe and Jenkins 2005). Additionally, scholars have argued that under certain situations, such as when the issue under consideration is less salient or when the legislator is moderate, contributions are more likely to have an impact.

However, while many studies have looked at the impact of contributions on roll call voting at the national level, few have looked at the same question at the state level. ${ }^{1}$ In fact, recent reviews of the literature on this topic identify only two analyses, each looking at one state, that deal with the impact of such contributions at the state level (Roscoe and Jenkins 2005; Smith 1995). As Roscoe and Jenkins $(2005,56)$ note, "political science can speak fairly confidently about the influence of contributions in the House, but has little to say about the role of money in different legislative venues."

SHANNON JENKINS is an associate professor of political science at the University of Massachusetts Dartmouth.

The American Review of Politics, Vol. 32, Fall, 2011: 233-258

(c)2011 The American Review of Politics 
The only multi-state study of the influence of interest groups on legislative behavior in the states, by Wiggins, Hamm and Bell (1992), looks at the success rate of groups on bill passage as compared to party leaders and governors, rather than the impact of groups on individual legislators. This lack of focus on state legislative behavior is problematic as a great deal of policy-making occurs at the state level and significant amounts of money are spent to influence state politics.

As Squire and Hamm $(2005,146)$ note, "truly generalizable theories should be portable from one American legislature to another." Thus, little is known about the impact of contributions on roll call voting at the state level and about the generalizability of theories of interest group influence outside of Congress. This analysis attempts to remedy this deficiency by examining the impact of PAC contributions over roll call voting across a broad range of issue areas in three state legislatures, both upper and lower chambers, in the 1997-1998 legislative session. In doing so, the goal is to test theories of interest group influence at the state level and to better understand the conditions under which contributions are more likely to influence legislative behavior. Is it the case that contributions have more influence over roll call voting at the state level as there is some evidence that state politics is less visible than national politics? Or do the dynamics that operate at the national level also operate at the state level, with influence emerging under specific conditions? Or are the relationships between contributions and votes at the state level completely different than those found at the national level?

\section{The Influence of Campaign Contributions on Roll Call Voting}

While there is a sizable correlation between campaign contributions and roll call votes, studies examining the impact of campaign contributions on roll call voting at the national level have generally found that such contributions rarely influence votes. As Wright $(1996,137)$ notes, "the apparent connections between money and voting are generally spurious - that is, they result not from selling and buying votes on the part of PACs and legislators, but instead from more basic partisan and ideological behavior." However, a significant minority of studies have found a connection between contributions and votes even when controlling for partisan and ideological tendencies (Fleisher 1993; Langbein and Lotwis 1990; Stratmann 1991; Welch 1982; Wilhite and Thielman 1987). Roscoe and Jenkins (2005) conduct a meta-analysis of studies examining the relationship between campaign contributions and roll call votes; they estimate that approximately 25-35 percent of all roll call votes examined show evidence of influence from campaign contributions. 
Scholars have speculated about why contributions influence votes in some situations but not in others. They argue that interest groups will have more influence when the issue under consideration is low visibility, specialized, technical or narrow, non-partisan and/or non-ideological. In addition, group influence is more pronounced when the public is indifferent, divided or ignorant, and the general political climate or opinion is consistent with the objective of the interest group. Other conditions that enhance group influence include when the position advocated by the interest group is unopposed by any other interest groups, the group lobbies the issue intensely, an election is drawing near, members are facing or have faced a close election, and members are ideologically moderate (Smith 1995, 94-95). Furthermore, studies at the congressional level suggest the greatest potential for influence seems to stem from contributions from business and labor (Neustadtl 1990; Quinn and Shapiro 1991; Saltzman 1987; Wilhite and Thielman 1987). However, these theories have generally been developed and tested only in Congress. Little research examines the relationship between contributions and votes at the state level, so it is not clear the extent to which these patterns hold true in the states.

On the one hand, it may be that contributions influence roll call votes more frequently at the state level than at the national level. Some research has shown that state politics tends to be less visible and salient than national politics to the mass public (Jennings and Zeigler 1970; Patterson 1991). For example, one survey of Coloradans found that 85 percent of those surveyed could not name their state senator or representative (Cronin and Loevy 1993, 117). It seems reasonable to presume that if the majority of people could not even name their elected officials, even fewer would be able to name their votes, even on the most important issues. If roll call voting in state legislature is generally low visibility and the public is largely uninformed, then these are two conditions where national level research would lead us to expect more frequent influence. Thus, it may be that interest groups will influence roll call voting at the state level more frequently than at the national level.

On the other hand, it may be true that the same dynamics that operate at the national level also operate at the state level, with campaign contributions infrequently influencing roll call votes and with such influence emerging in specific situations, such as over legislators who are moderates or on low visibility votes. For example, Hersch and McDougall's (1988) study examining the impact of campaign contributions on votes for pari-mutuel wagering, a state operated lottery, and liquor-by-the-drink sales in Kansas found no impact for contributions on these high visibility votes, confirming findings at the national level that such influence is less likely on high visibility, high salience issues. 
Conversely, it may be that the relationship between votes and contributions at the state level is different from that at the national level. For example, research at the congressional level has shown that business and labor interests influence roll call votes more frequently than other interests (Neustadtl 1990; Quinn and Shapiro 1991; Saltzman 1987; Wilhite and Thielman 1987). However, Dow and Endersby's (1994) study found that neither the number nor the amount of contributions by business organizations in California influence roll call voting. Additionally, it may be the case that the relationship between roll call voting and campaign contributions varies from state to state. It may be the case that in some states, patterns of influence resemble those at the national level while in other states, influence is more or less frequent. Without examining the relationship between money and votes across multiple states and in many issue areas, the extent to which these theories hold in other legislative venues is unclear.

\section{Data and Methods}

The states chosen for this analysis were Colorado, Illinois, and Missouri; these states are a subsample of those states surveyed for the Election Dynamics Project (EDP) conducted by John Frendreis and Alan Gitelson. ${ }^{2}$ Research has shown the importance of controlling for ideology in looking for the influence of contributions over roll call voting (Roscoe and Jenkins 2005); the EDP survey includes a measure of ideology which allows for such controls to be included in this analysis, a key reason for selecting these states. Clearly, these states do not constitute a random sample of the states, so care must be taken when generalizing these findings across states. However, there are features of the political systems in Colorado, Illinois, and Missouri that suggest there is greater potential for campaign contributions to impact roll call voting here as compared to the national level. In the 1996 election cycle, none of the states examined here had limits on campaign contributions from corporations, labor unions, and political action committees to legislative candidates. Analysis by the Center for Public Integrity (1999) found that these three states received poor scores with respect to ethics, conflict of interest, and financial disclosure laws; Illinois received a failing grade for disclosure, while Colorado and Missouri received barely passing grades. A more recent analysis by the Center for Public Integrity (2006) found all three states had lower disclosure of campaign contribution scores than those at the national level and gave Colorado and Missouri D's, while Illinois received an $\mathrm{F}$.

Furthermore, ratings of the impact of interest groups in these states show that groups play a strong role in influencing politics. ${ }^{3}$ Thomas and Hrebenar $(1996,152)$ note that in Colorado and Missouri interest groups 
play a complementary role in influencing state policy, while in Illinois they play a dominant/complementary role. Brace and Straayer $(1987,56)$ argue groups in Colorado employ sophisticated lobbying techniques and strategic campaign funding efforts, and that these efforts appear to make a difference in who runs and wins in legislative races. In Illinois, campaign costs have increased greatly; in one study, campaign costs in Illinois ranked second only to California, a much larger state (Moncrief 1998). As a result, PACs have become an increasingly important source for financing campaigns (Everson and Gove 1993). In Missouri, with the emergence of the Republican party during this period, interest groups began to grow in number and influence, and PAC contributions have become an important source of revenue for candidates (Valentine 1995).

Thus, these states tend to be characterized by moderately strong interest group systems, with business and industry groups playing a particularly strong role in influencing the process (Brace and Straayer 1987; Everson and Gove 1993; Morehouse 1981; Valentine 1995). Moreover, groups play a strong role in financing campaigns in these states. Candidates' reliance on PACs for funding would seem to produce ripe conditions for influencing voting here. It may be that the influence of campaign contributions is different in other states as compared to these states, but this small sample allows for an examination of how lax campaign finance regulations affect the relationship between giving and voting and how these relationships differ in the states as compared to the national level.

The dependent variables utilized in this analysis will be issue area scores for the 1997-1998 legislative sessions in these chambers. These scores record the proportion of times a legislator voted liberally in a given issue area. Scores were created in the following categories: abortion; agriculture; appropriations, budget, and revenue; economic regulatory (banking, finance, business, communications, and telecommunications); campaign finance, politics, and elections; legislative affairs; crime and criminal justice; education; environment, recreation, and parks; executive branch (appointments) and oversight; local government; gun control and hunting; health, welfare, family, and children; labor and labor unions; law and judiciary; taxes and taxation; transportation; social security, retirement and pensions; procedural; and lottery and gambling. ${ }^{4}$

Once these categories were developed, all bills voted on in the 19971998 session in each of these state legislatures were assigned an issue area code based on brief summaries of each bill provided by the state legislative journals or the official state legislature website. For Colorado and Missouri, all recorded roll call votes (including procedural votes) with more than 10 percent dissenting votes were included. For Illinois, the Almanac of 
Illinois Politics (Joens and Kleppner 1998) selected important votes for each legislative session; all of these important votes were used in this analysis. ${ }^{5}$

For each legislator, the number of liberal votes cast in each issue area was divided by the number of total votes cast in that area for a score that ranges from 0 to 1.0 (missing votes were not counted). ${ }^{6}$ Low scores represent a tendency to vote conservatively, while high scores represent a tendency to vote liberally. So for example, a legislator who voted liberally on 2 of 10 abortion votes would have a score of .2 , indicating a tendency to vote conservatively. Table 1 show descriptive statistics for the issue area scores.

The key independent variable in this analysis is the amount of campaign contributions in the 1996 election cycle from interest groups, summarized by type. Information on campaign contributions came from the Institute on Money in State Politics (http://www.followthemoney.org/). The Institute on Money in State Politics provides total contributions received by a candidate as well as how much of this total comes from 13 sectors: agriculture, candidate contributions, communications and electronics, construction, energy and natural resources, finance, insurance and real estate, general business, health, ideology/single issue, labor, lawyers and lobbyists, other/ retiree/civil servants, party, and transportation. ${ }^{7}$ The Institute on Money in State Politics also breaks these totals down into subcategories within each

Table 1. Issue Area Scores Descriptive Information

\begin{tabular}{lrrrrrr}
\hline & \multicolumn{2}{c}{ Colorado } & \multicolumn{2}{c}{ Illinois } & \multicolumn{2}{c}{ Missouri } \\
Issue Area Codes & House & Senate & House & Senate & House & Senate \\
\hline Abortion & 1 & 0 & 4 & 1 & 4 & 0 \\
Agriculture & 6 & 6 & 1 & 0 & 5 & 7 \\
Crime and Criminal Justice & 36 & 30 & 5 & 4 & 21 & 15 \\
Economic Regulatory & 41 & 33 & 13 & 2 & 37 & 10 \\
Education & 29 & 32 & 7 & 6 & 25 & 10 \\
Environment, Recreation & & & & & & \\
$\quad$ Parks & 33 & 27 & 6 & 4 & 10 & 10 \\
Gun Control, Hunting & 6 & 3 & 2 & 1 & 5 & 2 \\
Health, Welfare, Family, & & & & & & \\
$\quad$ Children & 64 & 50 & 19 & 2 & 45 & 15 \\
Labor and Labor Unions & 18 & 7 & 1 & 0 & 4 & 2 \\
Law and Judiciary & 16 & 6 & 1 & 0 & 16 & 14 \\
Lottery and Gambling & 8 & 2 & 2 & 2 & 8 & 9 \\
$\begin{array}{l}\text { Pensions, Retirement, } \\
\quad \text { and Social Security }\end{array}$ & 9 & 5 & 0 & 0 & 12 & 4 \\
$\quad$ Taxes & 35 & 25 & 5 & 2 & 23 & 13 \\
Transportation & 45 & 26 & 8 & 5 & 25 & 12 \\
$\quad$ Note: Entries in cells represent the number of votes in each issue area. & & & \\
\hline
\end{tabular}


sector. So, for example, the health sector includes subcategories for health professionals, hospitals and nursing homes, pharmaceuticals, health services, and miscellaneous health. In almost all cases, the total sector contribution amount was used in the analysis. However, in some sectors, the subcategories were used. For instance, the ideology/single issue sector includes many subcategories (16 in all), some of which are in direct opposition to each other, such as the pro-life and pro-choice subcategories. Here, it did not make sense to include the sector totals, so the subcategory amounts were used instead. In addition, a total business contribution score was developed which represents the sum of contributions from communications and electronics, construction, energy and natural resources, finance, insurance and real estate, general business, and transportation PACs. While actual dollar amounts were entered, the actual contributions variables used in the analysis were recorded in the thousands of dollars.

There is a good deal of variation in the amounts of money raised across the states. For example, in the Colorado house, the average amount raised by state legislators in the 1996 election cycle was $\$ 32,164$, while the average raised by state legislators in the Illinois house was $\$ 221,941$. Across all of these states, business contributions account for the largest portion of the contributions. For example, in the Colorado house, the average contribution from general business PACs was approximately $\$ 4,100$, or about 12.7 percent of total receipts, while in Illinois, the average contribution from general business PACs was $\$ 18,600$, or approximately 8.3 percent of the total.

Next, these PACs were matched to the issue area scores. For several types of issue areas, there were a number of contributions that might potentially affect voting in that area. For example, on environmental votes, not only might contributions from environmental groups (a sub-category of ideology/single issue) induce more pro-environmental voting, but more contributions from business groups might induce less environmentally friendly voting. Thus, many of the issue area scores were correlated with multiple contributions. ${ }^{8}$ Furthermore, these sectors identified by the Institute on Money in State Politics can be further broken down and in some cases, they are for this analysis. For instance, for abortion votes, contributions from a variety of liberal issue groups and contributions from a variety of conservative issue groups (each group was a separate sub-category) were used in the analysis rather than the overall ideology/single issue category, as some of the sub-categories, such as anti-gun control groups, are not relevant for these votes.

Any study examining the relationship between roll call votes and campaign contributions must control for the problem of friendly giving. There are two common ways to deal with this problem, the use of simultaneous 
equations or the use of an ideology variable. Roscoe and Jenkins (2005) find in their meta-analysis that the inclusion of an ideology variable has a significant impact on the likelihood of significant findings, while the use of simultaneous equations model does not. As they state, "the only effective way to control for friendly giving is to include an ideology variable in the equation" (63). As part of the EDP, all general election state legislative candidates from the Democratic and Republican parties were surveyed during the 1996 election cycle. Importantly, the survey asked respondents to place themselves on a liberal-conservative scale, ranging from strongly conservative (1) to strongly liberal (7). The responses to this question served as a key independent variable in this analysis. These surveys were matched to the roll call voting records of legislators for the session following. So, for this analysis, 1996 surveys were matched to the 1997-1998 issue area scores. ${ }^{9}$ This analysis focused on a subset of survey respondents, namely those state legislative candidates who were elected to office and became state legislators. Of those who returned surveys, 210 came from winning candidates in Colorado, Illinois, and Missouri legislature; 146 of these were from the lower chambers, while 64 were from the upper chambers. ${ }^{10}$

The other independent variables in this analysis are constituency and party. I would like to have controlled for constituency preferences, but these measures are unavailable at the state legislative district level as are district presidential returns. Demographic variables will be utilized as proxies (albeit imperfect ones) for constituency opinion. While the use of these data is less than ideal, controls for the opinions of constituents must be included in the model. Because, arguably, preferences are to a significant degree a function of social and economic characteristics, demographics will serve as a proxy measure of those preferences.

Candidate survey responses were matched to legislative district demographic data from the 1990 census taken from the Almanac of State Legislatures. The set of demographics utilized here included race, defined as percent black; ethnicity, defined as percent Hispanic; income level, defined as the average income in a district; and a measure of how rural/agricultural a district is, which was operationalized as the percent who farm for a living. Finally, party was simply measured as the legislators' partisan identification, either Democrat (1) or Republican (0).

In addition, since research at the congressional level indicates that the influence of contributions is more likely when legislators have faced a close election and when members are ideologically moderate (Smith 1995, 94-95), two interaction variables were created for each contribution variable to test for the possibility that contributions had a greater influence on these types of legislators. First, a dummy variable for ideological moderates was created; this variable was equal to one for all legislators who selected moderate on 
the ideology scale and zero for all others. This dummy variable was interacted with each of the contributions variable. Second, an interaction variable was created for those legislators in close elections. The EDP asked legislators how competitive their race was, with responses ranging from (1) very competitive to (5) no opposition. As it seems that legislators who feel unsafe will act differently than those who feel safe, this measure was used in lieu of actual margin of victory. Thus, a dummy variable for competitive races was created; this variable was equal to one for legislators who said their race was very competitive, which was approximately 27.8 percent of respondents, and zero for all others. This dummy variable was also interacted with each of the contributions variables. For each of these interactions, any time a contribution variable was included in an equation, the interaction variables were also included. In order to properly interpret these interaction variables, the dummy variables were also included in the models (Brambor et al., 2006). These interaction variables capture the additional effect of contributions on moderates and those in competitive races, over and above any effect the contributions variable has on its own.

OLS regression was used to examine the relationship between campaign contributions and roll call voting; these models control for the constituency, partisan identification and ideology of the state legislators under examination here. Two analyses were run. In the first, the states were pooled and robust clustered standard errors were used to account for the fact that cases in a group may be related in some way; they are clustered around the state and chamber. Additionally, the analyses were run separately for each state. Because group influence emerges in different areas in the various states, these are the results that are reported below. ${ }^{11}$

\section{Results}

Given the large number of regression models (41), the effects of the contributions variables alone are reported in Table 2; these effects and standard errors were calculated as recommended in Brambor et al. (2006). The full results can be found in the Appendix. Generally speaking, the control variables in the model operate in the expected manner. Democrats are more likely to vote liberally as are liberals; Republicans and conservatives are less likely to vote liberally. Party is significant in slightly more than 75 percent of the models, while ideology is significant in a little more than 63 percent of the models. The constituency variables are significant in about 15 percent of the cases across these states. ${ }^{12}$ The lack of significance for the constituency variables should be taken with a grain of salt, due to the measures used; perhaps with more accurate measures of constituency opinion, these variables would be significant more frequently. While the constituency variables 


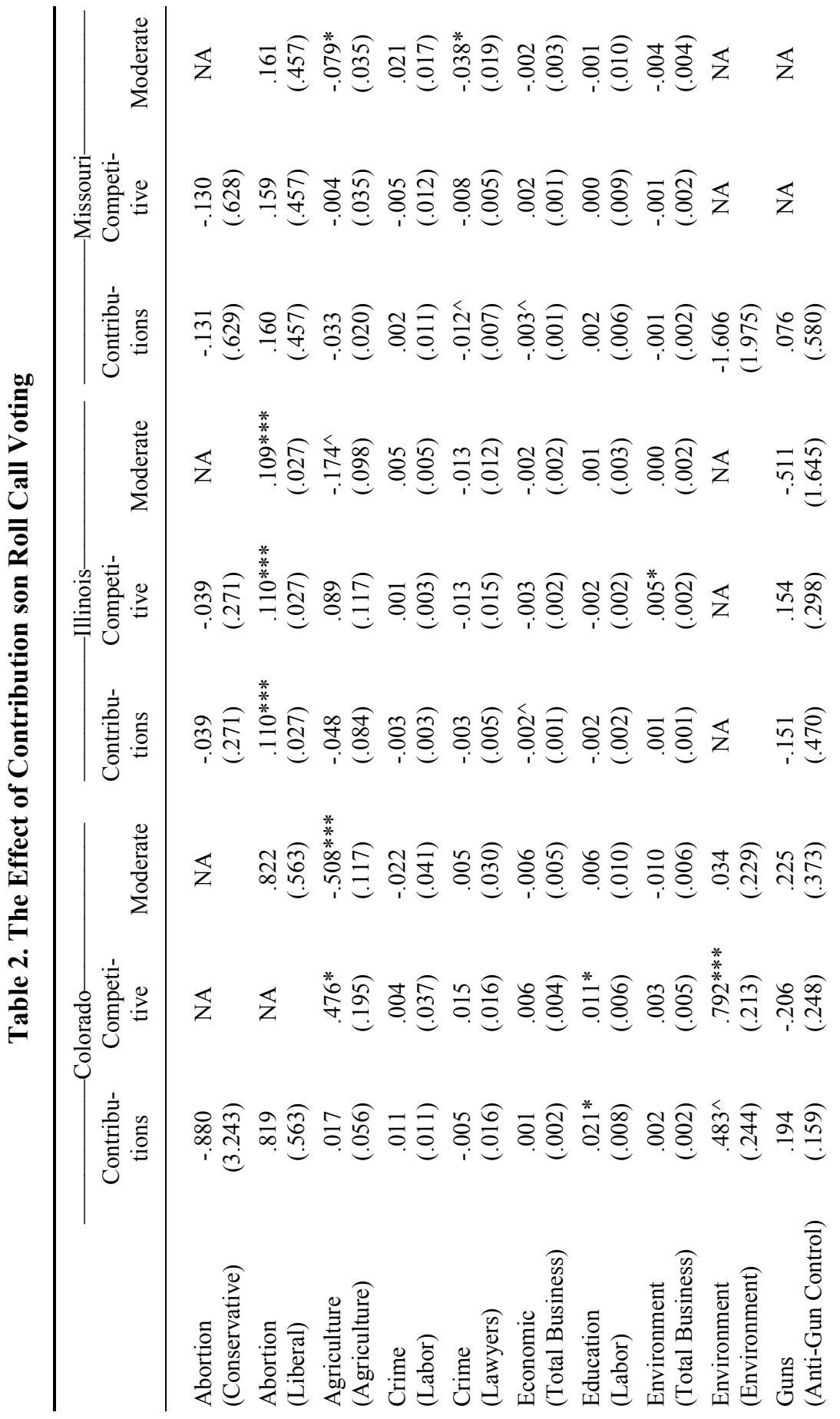




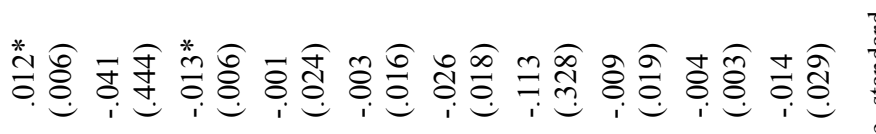

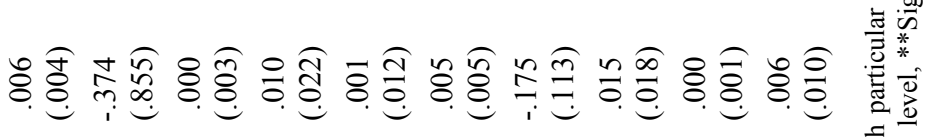

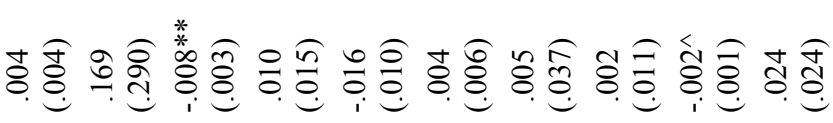

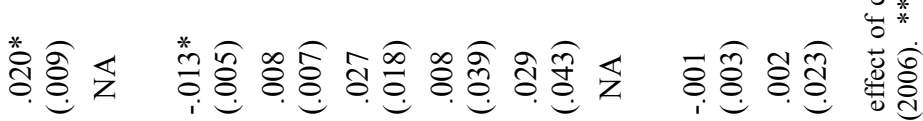

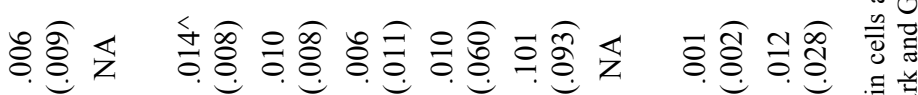

8.

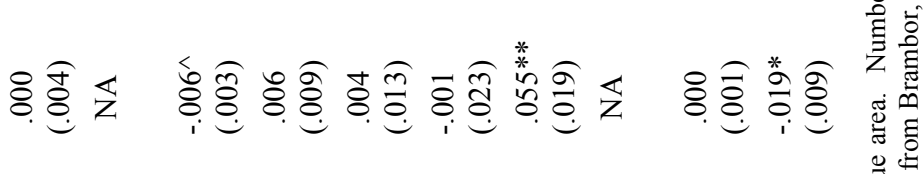

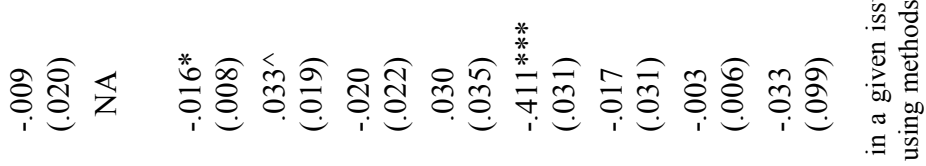

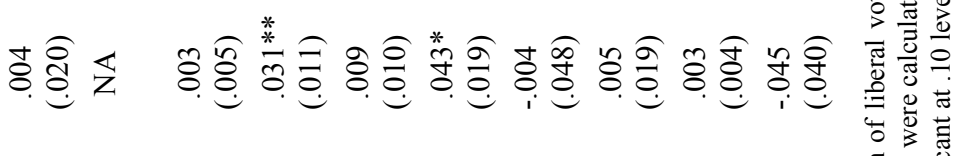

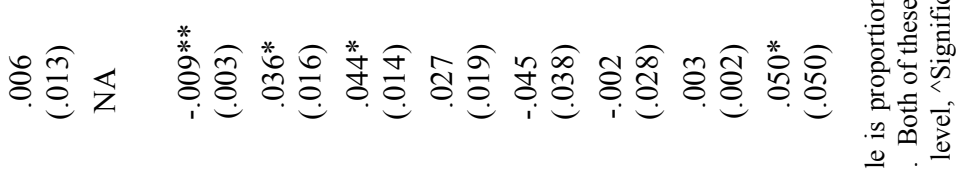

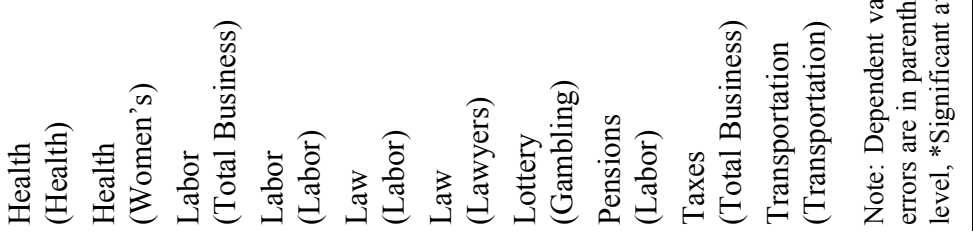


are significant at about the same rate in these states, the same is not true for the party and ideology variables. For instance, party is significant in 13 of the 14 models in Colorado, but only 7 of 13 in Illinois. Ideology is significant in 50 percent of the models in Missouri; in Colorado, it is significant in over 78 percent of the models.

The moderate dummy variable is rarely significant; in Colorado, the variable is significant in three models. Here, moderates are more likely to vote liberally on abortion, environment, and law votes. This variable is only significant once in both Illinois and Missouri; in these states, moderates vote more conservatively on law votes in Illinois and on health votes in Missouri. Conversely, the competition variable consistently induces more conservative voting in these states when the variable is significant. Legislators in more competitive races vote more conservatively for agriculture and labor votes in Colorado; for agriculture, environment, labor, and transportation votes in Illinois; and for economic votes in Missouri.

Of greater interest here are the contributions variables; the results reveal that contributions affect roll call votes in these states at about the same rate that they do at the national level. Roscoe and Jenkins (2005) estimate that campaign contributions affect roll call votes approximately 25-35 percent of the time; 34 of the 159 campaign contributions variables included in these models are significant, for a rate of approximately 21.4 percent. However, the rate of significant links varies from state to state. In Colorado, significant links are more frequent as 14 of the 54 contribution variables have a significant relationship to roll call voting $(25.9 \%)$; the same is true in Illinois where 12 of the 50 contributions variables were significant (24\%). In these two states then, contributions significantly influence roll call voting at approximately the same frequency they do at the national level. But in Missouri, significant links are less frequent as only 7 of 55 contributions were significant $(14.5 \%)$.

In most cases, the effect of these variables is as expected. Contributions from labor unions produce more liberal voting records, while contributions from business groups produce more conservative voting records. There are some exceptions to this though. Transportation contributions produce more liberal votes in Colorado; this may indicate that a liberal vote equals support for more government transportation spending, which may include transportation public works projects and which transportation interests may support. However, transportation contributions are negatively related to these votes in Illinois, so these significant relationships may be related to the specific nature of bills that were under consideration in these states.

In about half of the cases (14 of 34 significant relationships), it is the contributions variable that is significant; the moderate interaction variable is significant 12 times, while the competitive interaction variable is significant 
8 times. There are two important things to note here. First, these variables sometimes operate in the opposite manner of the main contributions variable, diminishing the overall effect of money in these races. For example, for Illinois labor votes, legislators who receive more contributions from businesses are significantly more likely to vote conservatively, but moderate legislators who receive more contributions from businesses are more likely to vote liberally. In fact, in four of the ten models where multiple contributions variables are significant, the interaction variable has the opposite effect of the contribution variable (agriculture votes in Colorado and labor votes for business contributions in Illinois), or it diminishes the effect of the main variable (education and labor votes for labor contributions in Colorado). ${ }^{13}$

Second, while the significant results are fairly evenly divided between competitive races and moderate legislators in Colorado and Illinois, the competitive interaction variable is never significant in any of the models in Missouri. Why this is the case remains unclear and warrants further investigation. Nonetheless, these findings confirm results from the national level that indicate moderates and legislators in competitive races are more likely to be influenced by campaign contributions, but the results here also suggest that groups may be strategically giving in some cases. Since the contribution variables sometimes act in the opposite direction of what was expected, this suggests that groups are giving to candidates who may be less than optimal (from the group's perspective) with respect to policy, but whose opponent may be worse. For example, unions may give money to a candidate in a close race who is less likely to support the union's position, but the opponent of that candidate may be even less likely to support the union's position.

These results also confirm findings at the national level (Neustadtl 1990; Quinn and Shapiro 1991; Saltzman 1987; Wilhite and Thielman 1987) and previous examinations of the group systems in these states that suggest business and labor interests have a stronger influence than other types of groups (Brace and Straayer 1987; Everson and Gove 1993; Morehouse 1981; Valentine 1995). Of the significant contributions, 21 of them were from unions or business related interests (total business, gambling, transportation, and health). This may simply reflect the fact that these variables were included in the models more frequently. But this was a due to the fact that few non-business groups were active in giving in these states. For example, contributions from women's organizations could not be included for Colorado or Illinois health votes because there were none, despite the fact that there are many active women's issue PACs active at the national level. In the end then, business and labor groups are more likely to influence voting, but this is due in part because they are more active than other groups in contributing to campaigns. 
Once again, it is important to note that the pattern of significant relationships with respect to unions and business groups varies from state to state. All of the significant relationship for the union variables are found in Colorado; these variables are never significant in Illinois or Missouri. This is particularly striking on labor related votes. In all of these states, contributions from business interests produce more conservative voting records, but only in Colorado are these effect offset by the contributions of labor unions.

Next, the results here run counter to the research at the national level that found contributions were more likely to influence less salient votes. While there were no significant relationship for gun related votes, a salient issue, the contributions of liberal groups had significant effects on abortion votes in Illinois. Furthermore, there are only two issue areas (guns and pensions) where significant relationships were not found in any of the states; while gun related votes are clearly salient issues, pension votes did not seem to be particularly salient during the time under examination here. In fact, in none of these states does there appear to be a clear pattern where contributions are related to non-salient issues only. Thus, the paucity of significant relationships between contributions and salient roll call votes appears to be a finding that is particular to the U.S. Congress.

Finally, these results highlight the last important finding of this analysis: the pattern of significant relationships varies from state to state. Of the 12 issue areas where significant relationships were found, contributions variables are significant in multiple states in slightly more half of them (agriculture votes in Colorado and Missouri, crime and health votes in Illinois and Missouri, education, law, and transportation votes in Colorado and Illinois, and labor votes in all three states). And, in each state, there is at least one issue area where there is a significant relationship between votes and contributions in that state, but not in any other. For example, contributions from environmental groups had a significant impact on roll call voting in Colorado as did law contributions on law votes, but not in Illinois or Missouri. The same is true for abortion votes in Illinois and tax votes in Missouri. Now, this may be due to peculiarities in the agenda in this particular session in a given state, but it does illustrate the difficulty in developing generalizations about the nature of the relationship between campaign contributions and roll call votes when looking at only one chamber.

\section{Discussion}

In the end, this analysis confirmed some of the findings from the national level about the relationship between roll call votes and interest group contributions; at the same time, it also calls into question some of the conventional wisdom about the nature of these relationships. First, contribu- 
tions influence roll call votes at about the same frequency at the state level as they do at the national level: about a quarter of the time. Of course, this average masks some variation in the frequency of the significant results in each state. There were significant relationships about 26 percent of the time in Colorado, about 24 percent of the time in Illinois, and 15 percent of the time in Missouri. Thus, contributions do influence roll call votes in a substantial minority of cases here.

The results also confirm national findings that labor and business contributions are more likely to influence roll call votes than other kinds of groups. This may be due to the fact that these groups simply contribute more than other types of groups. Total Business contributions dwarf all other contributions (not surprising given that this category is a total of several other categories), but unions also give a significant amount as well. However, this activity is also a reflection of the fact that these groups are simply the most active and powerful groups at the state level (Nownes et al., 2008). Here again, though, the pattern of significant relationship varies, with unions play a strong role in Colorado, whereas business interests were more dominant in Illinois and Missouri.

Moderates and legislators in competitive races were more likely to be influenced by campaign contributions. However, after controlling for party, ideology, and constituency factors, the results show these contributions sometimes have the opposite of the intended effect, suggesting that groups may be strategically pursuing an electoral strategy at the state level.

Finally, the incidence of significant relationships in these states did not appear to be related to issue salience. There were significant relationships between contributions and roll call votes in several salient issue areas in these states, most notably abortion votes. This ties into the finding that the relationships between these contributions and roll call votes varies from state to state. In Illinois, where important votes were examined, contributions and votes were significantly related in several issue areas that might be considered salient, such as abortion and lottery and gambling. Conversely, in Colorado, the pattern of significant relationships by issue more closely resembles patterns found at the national level; there were no significant relationships for salient issues like abortion, guns and gambling.

It may be the case that variations in the nature of the agenda explain these differences. As Dow and Endersby $(1994,349)$ point out, influence arrangements may exist among specific groups and legislators in reference to particular bills and if this is the case, then such influence may be lost in the aggregation to issue areas and PAC types. This analysis also does not account for any log rolling or vote trading that may be occurring on specific bills nor does it account for the potential that there may be salient individual bills in any given issue area. Given the large number of votes included in 
this analysis (over 1100), such analysis is not possible here, but further investigation is needed to rule out such possibilities.

It is also important to point out that although these results examine the relationship between campaign contributions and roll call voting generally, that does not mean that interest groups do not have other methods for influencing state politics and policy. Despite the fact that interest group contributions do not influence roll call votes most of the time, interest groups may pursue other strategies. For example, it may be that contributions help groups keep items from ever being considered for roll call votes or that contributions buy time and activity from legislators. Some research into these avenues for group influence has been done at the national level (Baumgartner and Jones 1993; Kingdon 1984), but little research looks at these questions at the state level. Future research into these avenues for group influence at the state level is worth pursuing.

Significant questions still remain about the relationship between interest group activity and legislative behavior at the state level and generally. While this analysis confirms some findings from the national level, leading to greater certainty about the general applicability of these findings, others, such as the role of issue salience, were not confirmed. While some have argued that political scientists know all we need to know about the relationship between contributions and roll call votes, these analyses reveal that continued research into this subject is warranted. 
APPENDIX

Table A1. The Influence of Contributions on Roll Call Votes in Colorado

\begin{tabular}{|c|c|c|c|c|c|c|c|}
\hline & Abortion & $\begin{array}{l}\text { Agri- } \\
\text { culture }\end{array}$ & Crime & $\begin{array}{l}\text { Eco- } \\
\text { nomic }\end{array}$ & $\begin{array}{l}\text { Educa- } \\
\text { tion }\end{array}$ & $\begin{array}{c}\text { Environ- } \\
\text { ment }\end{array}$ & Guns \\
\hline Party & $\begin{array}{l}.523 * * \\
(.151)\end{array}$ & $\begin{array}{c}.181^{*} \\
(.068)\end{array}$ & $\begin{array}{l}.245 * * * \\
(.048)\end{array}$ & $\begin{array}{l}.344 * * * \\
(.042)\end{array}$ & $\begin{array}{l}.222^{* * *} \\
(.035)\end{array}$ & $\begin{array}{l}.251 * * * \\
(.057)\end{array}$ & $\begin{array}{c}.423 * * * \\
(.073)\end{array}$ \\
\hline Ideology & $\begin{array}{l}.147 * \\
(.063)\end{array}$ & $\begin{array}{l}.044 \\
(.027)\end{array}$ & $\begin{array}{l}.046^{*} \\
(.018)\end{array}$ & $\begin{array}{l}.066^{* * *} \\
(.017)\end{array}$ & $\begin{array}{l}.057^{* * * *} \\
(.013)\end{array}$ & $\begin{array}{l}.103 * * * \\
(.023)\end{array}$ & $\begin{array}{c}.081 * \\
(.030)\end{array}$ \\
\hline$\%$ Black & $\begin{array}{l}.000 \\
(.007)\end{array}$ & $\begin{array}{l}-.002 \\
(.003)\end{array}$ & $\begin{array}{l}-.001 \\
(.002)\end{array}$ & $\begin{array}{l}-.004^{\wedge} \\
(.002)\end{array}$ & $\begin{array}{l}.001 \\
(.002)\end{array}$ & $\begin{array}{l}-.003 \\
(.003)\end{array}$ & $\begin{array}{l}-.002 \\
(.003)\end{array}$ \\
\hline$\%$ Farm & $\begin{array}{l}.007 \\
(.016)\end{array}$ & $\begin{array}{l}.003 \\
(.006)\end{array}$ & $\begin{array}{l}.001 \\
(.005)\end{array}$ & $\begin{array}{l}.002 \\
(.004)\end{array}$ & $\begin{array}{l}.000 \\
(.003)\end{array}$ & $\begin{array}{l}.003 \\
(.005)\end{array}$ & $\begin{array}{l}-.005 \\
(.007)\end{array}$ \\
\hline \% Hispanic & $\begin{array}{l}.001 \\
(.013)\end{array}$ & $\begin{array}{l}-.003 \\
(.004)\end{array}$ & $\begin{array}{l}.000 \\
(.003)\end{array}$ & $\begin{array}{l}-.001 \\
(.002)\end{array}$ & $\begin{array}{l}.001 \\
(.002)\end{array}$ & $\begin{array}{l}-.001 \\
(.003)\end{array}$ & $\begin{array}{l}-.002 \\
(.004)\end{array}$ \\
\hline Income & $\begin{array}{l}.006 \\
(.009)\end{array}$ & $\begin{array}{l}-.002 \\
(.004)\end{array}$ & $\begin{array}{l}-.001 \\
(.003)\end{array}$ & $\begin{array}{l}-.004^{\wedge} \\
(.002)\end{array}$ & $\begin{array}{l}-.003^{\wedge} \\
(.002)\end{array}$ & $\begin{array}{l}-.006^{*} \\
(.003)\end{array}$ & $\begin{array}{l}-.002 \\
(.004)\end{array}$ \\
\hline Moderate & $\begin{array}{l}.368^{*} \\
(.133)\end{array}$ & $\begin{array}{c}.063 \\
(.066)\end{array}$ & $\begin{array}{l}.038 \\
(.055)\end{array}$ & $\begin{array}{l}.041 \\
(.064)\end{array}$ & $\begin{array}{l}.027 \\
(.037)\end{array}$ & $\begin{array}{l}.175^{*} \\
(.085)\end{array}$ & $\begin{array}{l}.105 \\
(.067)\end{array}$ \\
\hline Competitive & $\begin{array}{l}.014 \\
(.133)\end{array}$ & $\begin{array}{l}-.122 * \\
(.058)\end{array}$ & $\begin{array}{l}-.071 \\
(.051)\end{array}$ & $\begin{array}{l}-.084 \\
(.051)\end{array}$ & $\begin{array}{l}.033 \\
(.032)\end{array}$ & $\begin{array}{l}-.091 \\
(.067)\end{array}$ & $\begin{array}{l}.013 \\
(.064)\end{array}$ \\
\hline $\begin{array}{l}\text { Contri- } \\
\text { butions } 1\end{array}$ & $\begin{array}{l}\text { Conser- } \\
\text { vative }\end{array}$ & $\begin{array}{l}\text { Agri- } \\
\text { culture }\end{array}$ & Labor & $\begin{array}{c}\text { Total } \\
\text { Business }\end{array}$ & Labor & $\begin{array}{l}\text { Total A } \\
\text { Business }\end{array}$ & $\begin{array}{l}\text { Anti-Gun } \\
\text { Control }\end{array}$ \\
\hline Contrib 1 & $\begin{array}{c}-.880 \\
(3.243)\end{array}$ & $\begin{array}{l}.017 \\
(.056)\end{array}$ & $\begin{array}{l}.011 \\
(.012)\end{array}$ & $\begin{array}{l}.001 \\
(.002)\end{array}$ & $\begin{array}{l}.021^{*} \\
(.008)\end{array}$ & $\begin{array}{l}.002 \\
(.003)\end{array}$ & $\begin{array}{l}.194 \\
(.159)\end{array}$ \\
\hline $\begin{array}{l}\text { Contrib } 1 \\
\text { Moderate } \\
\text { Contrib } 1 \\
\text { Competitive }\end{array}$ & NA & $\begin{array}{c}-.525 \\
(.320) \\
.459 \\
(.312)\end{array}$ & $\begin{array}{l}-.033^{\wedge} \\
(.019) \\
-.007 \\
(.013)\end{array}$ & $\begin{array}{l}-.007 \\
(.005) \\
.005 \\
(.004)\end{array}$ & $\begin{array}{l}-.015^{\wedge} \\
(.008) \\
-.010 \\
(.009)\end{array}$ & $\begin{array}{l}-.012 \\
(.007) \\
.001 \\
(.005)\end{array}$ & $\begin{array}{l}.031 \\
(.364) \\
-.400 \\
(.270)\end{array}$ \\
\hline $\begin{array}{l}\text { Contri- } \\
\text { butions } 2\end{array}$ & Liberal & & Lawyers & & & $\begin{array}{c}\text { Environ- } \\
\text { ment }\end{array}$ & \\
\hline Contrib 2 & $\begin{array}{c}.819 \\
(.563)\end{array}$ & & $\begin{array}{l}-.005 \\
(.016)\end{array}$ & & & $\begin{array}{c}.483^{\wedge} \\
(.244)\end{array}$ & \\
\hline $\begin{array}{l}\text { Contrib } 2 \\
\text { Moderate } \\
\text { Contrib } 2 \\
\text { Competitive }\end{array}$ & $\begin{array}{l}.003 \\
(.004) \\
\mathrm{NA}\end{array}$ & & $\begin{array}{c}.010 \\
(.028) \\
.020 \\
(.021)\end{array}$ & & & $\begin{array}{l}-.449^{\wedge} \\
(.310) \\
.309 \\
(.317)\end{array}$ & \\
\hline $\begin{array}{l}\text { Constant } \\
\mathrm{R}^{2} \\
\mathrm{~N}\end{array}$ & $\begin{array}{c}-.528 \\
.654 \\
32\end{array}$ & $\begin{array}{c}.542 \\
.336 \\
53\end{array}$ & $\begin{array}{c}.230 \\
.665 \\
53\end{array}$ & $\begin{array}{c}.398 \\
.808 \\
53\end{array}$ & $\begin{array}{c}.310 \\
.830 \\
53\end{array}$ & $\begin{array}{c}.268 \\
.776 \\
53\end{array}$ & $\begin{array}{c}.150 \\
.714 \\
53\end{array}$ \\
\hline
\end{tabular}

Note: Dependent variable is proportion of liberal votes in a given issue area. District average income and contributions are measured in thousands of dollars. Numbers in cells are unstandardized regres- 
APPENDIX (continued)

Table A1 (continued)

\begin{tabular}{|c|c|c|c|c|c|c|c|}
\hline & Health & Labor & Law & Lottery & $\begin{array}{l}\text { Pen- } \\
\text { sions }\end{array}$ & Taxes ${ }^{\mathrm{T}}$ & $\begin{array}{c}\text { Transpor- } \\
\text { tation }\end{array}$ \\
\hline \multirow[t]{2}{*}{ Party } & $.260 * * *$ & $.379 * * *$ & $* .246^{* * *}$ & .113 & $.389 * *$ & $.304 * * *$ & $* .164 * * *$ \\
\hline & $(.014)$ & $(.047)$ & $(0.57)$ & $(.086)$ & $(.133)$ & $(.051)$ & $(.039)$ \\
\hline \multirow[t]{2}{*}{ Ideology } & $.088 * * *$ & $.047^{\wedge}$ & $.052 *$ & .021 & .011 & $.104 * * *$ & $* .054 * *$ \\
\hline & $(.016)$ & $(.026)$ & $(.021)$ & $(.034)$ & $(.042)$ & $(.021)$ & $(.015)$ \\
\hline \multirow[t]{2}{*}{$\%$ Black } & -.003 & .004 & -.001 & .001 & .003 & $-.005^{*}$ & .000 \\
\hline & $(.002)$ & $(.003)$ & $(.003)$ & $(.004)$ & $(.005)$ & $(.002)$ & $(.002)$ \\
\hline \multirow[t]{2}{*}{$\%$ Farm } & $.008^{*}$ & -.008 & -.009 & .012 & .014 & .002 & .005 \\
\hline & $(.004)$ & $(.006)$ & $(.005)$ & $(.008)$ & $(.010)$ & $(.005)$ & $(.004)$ \\
\hline \multirow[t]{2}{*}{ \% Hispanic } & -.002 & .005 & -.001 & $.009^{\wedge}$ & .006 & -.002 & .000 \\
\hline & $(.002)$ & $(.003)$ & $(.003)$ & $(.005)$ & $(.006)$ & $(.003)$ & $(.002)$ \\
\hline \multirow[t]{2}{*}{ Income } & $-.004^{\wedge}$ & -.001 & -.003 & .005 & -.001 & $-.005^{\wedge}$ & -.002 \\
\hline & $(.002)$ & $(.003)$ & $(.003)$ & $(.005)$ & $(.006)$ & $(.003)$ & $(.002)$ \\
\hline \multirow[t]{2}{*}{ Moderate } & .058 & .011 & $.156^{*}$ & .076 & .038 & .031 & .042 \\
\hline & $(.062)$ & $(.097)$ & $(.064)$ & $(.098)$ & $(.122)$ & $(.077)$ & $(.052)$ \\
\hline \multirow[t]{2}{*}{ Competitive } & -.034 & $-.147^{\wedge}$ & -.100 & -.032 & .016 & -.043 & .019 \\
\hline & $(.054)$ & $(.084)$ & $(.060)$ & $(.072)$ & $(.103)$ & $(.062)$ & $(.037)$ \\
\hline $\begin{array}{l}\text { Contri- } \\
\text { butions } 1\end{array}$ & Health $\mathrm{B}$ & $\begin{array}{c}\text { Total } \\
\text { Business }\end{array}$ & Lawyer & $\begin{array}{c}\text { Gamb- } \\
\text { ling }\end{array}$ & Labor & $\begin{array}{c}\text { Total } \mathrm{T} \\
\text { Business }\end{array}$ & $\begin{array}{l}\text { Transpor- } \\
\text { tation }\end{array}$ \\
\hline \multirow[t]{2}{*}{ Contrib 1} & .006 & $-.009 * *$ & .027 & -.045 & -.002 & .003 & $.050 *$ \\
\hline & $(.013)$ & $(.003)$ & (.019) & $(.038)$ & $(.028)$ & $(.002)$ & $(.023)$ \\
\hline Contrib 1 & -.015 & -.007 & .003 & -.366 & -.015 & -.006 & -.083 \\
\hline Moderate & $(.023)$ & $(.008)$ & $(.033)$ & $(.373)$ & $(.028)$ & $(.006)$ & $(.100)$ \\
\hline Contrib 1 & -.002 & $.012 *$ & .016 & .041 & .007 & .000 & $-.095^{*}$ \\
\hline Competitive & $(.021)$ & $(.005)$ & $(.025)$ & $(.059)$ & $(.028)$ & $(.004)$ & $(.043)$ \\
\hline \multicolumn{8}{|l|}{ Contri- } \\
\hline \multirow[t]{2}{*}{ Contrib 2} & & $.036^{*}$ & $.044 * *$ & & & & \\
\hline & & $(.016)$ & $(.014)$ & & & & \\
\hline Contrib 2 & & -.003 & $-.064 * *$ & & & & \\
\hline Moderate & & $(.016)$ & $(.035)$ & & & & \\
\hline Contrib 2 & & -.005 & $-.035^{*}$ & & & & \\
\hline Competitive & & $(.016)$ & $(.015)$ & & & & \\
\hline Constant & .376 & .095 & .377 & -.016 & .259 & .198 & .373 \\
\hline $\mathrm{R}^{2}$ & .793 & .829 & .743 & .088 & .292 & .776 & .646 \\
\hline $\mathrm{N}$ & 53 & 53 & 53 & 53 & 53 & 53 & 53 \\
\hline
\end{tabular}

sion coefficients, standard errors are in parentheses: ***Significant at .001 level, **Significant at .01 level, *Significant at .05 level, ${ }^{\wedge}$ Significant at .10 level. 
APPENDIX (continued)

Table A2. The Influence of Contributions on Roll Call Votes in Illinois

\begin{tabular}{|c|c|c|c|c|c|c|c|}
\hline & Abortion & $\begin{array}{l}\text { Agri- } \\
\text { culture }\end{array}$ & Crime & $\begin{array}{c}\text { Eco- } \\
\text { nomic }\end{array}$ & $\begin{array}{l}\text { Educa- } \\
\text { tion }\end{array}$ & $\begin{array}{c}\text { Environ- } \\
\text { ment }\end{array}$ & Guns \\
\hline Party & $\begin{array}{l}-.053 \\
(.101)\end{array}$ & $\begin{array}{c}.199 \\
(.223)\end{array}$ & $\begin{array}{c}.061 \\
(.068)\end{array}$ & $\begin{array}{c}.183^{*} \\
(.071)\end{array}$ & $\begin{array}{l}.290^{* * * *} \\
(.058)\end{array}$ & $\begin{array}{c}* .076 \\
(.078)\end{array}$ & $\begin{array}{c}.054 \\
(.119)\end{array}$ \\
\hline Ideology & $\begin{array}{l}.218 * * * \\
(.043)\end{array}$ & $\begin{array}{c}.008 \\
(.088)\end{array}$ & $\begin{array}{l}.064^{*} \\
(.025)\end{array}$ & $\begin{array}{l}.065^{*} \\
(.028)\end{array}$ & $\begin{array}{l}.059 * * \\
(.022)\end{array}$ & $\begin{array}{l}.069 * \\
(.030)\end{array}$ & $\begin{array}{l}.170 * * \\
(.053)\end{array}$ \\
\hline$\%$ Black & $\begin{array}{l}.009 * * \\
(.003)\end{array}$ & $\begin{array}{l}-.001 \\
(.004)\end{array}$ & $\begin{array}{l}.004 * * \\
(.001)\end{array}$ & $\begin{array}{c}.000 \\
(.001)\end{array}$ & $\begin{array}{c}.001 \\
(.001)\end{array}$ & $\begin{array}{l}.000 \\
(.002)\end{array}$ & $\begin{array}{l}.005 \\
(.003)\end{array}$ \\
\hline$\%$ Farm & $\begin{array}{l}.014 \\
(.017)\end{array}$ & $\begin{array}{c}.046 \\
(.037)\end{array}$ & $\begin{array}{l}-.009 \\
(.010)\end{array}$ & $\begin{array}{l}-.004 \\
(.010)\end{array}$ & $\begin{array}{l}-.003 \\
(.008)\end{array}$ & $\begin{array}{l}-.024^{*} \\
(.001)\end{array}$ & $\begin{array}{l}-.001 \\
(.022)\end{array}$ \\
\hline$\%$ Hispanic & $\begin{array}{l}.008^{* *} \\
(.003)\end{array}$ & $\begin{array}{l}-.003 \\
(.005)\end{array}$ & $\begin{array}{c}.000 \\
(.002)\end{array}$ & $\begin{array}{c}.001 \\
(.002)\end{array}$ & $\begin{array}{c}.002 \\
(.002)\end{array}$ & $\begin{array}{l}.000 \\
(.002)\end{array}$ & $\begin{array}{l}.006 \\
(.003)\end{array}$ \\
\hline Income & $\begin{array}{l}.010 * * \\
(.003)\end{array}$ & $\begin{array}{l}.002 \\
(.006)\end{array}$ & $\begin{array}{l}.002 \\
(.002)\end{array}$ & $\begin{array}{l}.000 \\
(.002)\end{array}$ & $\begin{array}{l}.000 \\
(.001)\end{array}$ & $\begin{array}{l}-.001 \\
(.002)\end{array}$ & $\begin{array}{l}.011 * * \\
(.0003)\end{array}$ \\
\hline Moderate & $\begin{array}{l}.027 \\
(.091)\end{array}$ & $\begin{array}{c}.279 \\
(.216)\end{array}$ & $\begin{array}{l}-.106 \\
(.076)\end{array}$ & $\begin{array}{l}.091 \\
(.087)\end{array}$ & $\begin{array}{c}.019 \\
(.061)\end{array}$ & $\begin{array}{l}.070 \\
(.095)\end{array}$ & $\begin{array}{l}-.004 \\
(.105)\end{array}$ \\
\hline Competitive & $\begin{array}{l}.014 \\
(.106)\end{array}$ & $\begin{array}{l}-.816^{* *} \\
(.278)\end{array}$ & $\begin{array}{l}.026 \\
(.077)\end{array}$ & $\begin{array}{l}-.020 \\
(.094)\end{array}$ & $\begin{array}{l}-.048 \\
(.067)\end{array}$ & $\begin{array}{l}-.294 * * \\
(.103)\end{array}$ & $\begin{array}{c}.018 \\
(.117)\end{array}$ \\
\hline $\begin{array}{l}\text { Contri- } \\
\text { butions } 1\end{array}$ & $\begin{array}{l}\text { Conser- } \\
\text { vative }\end{array}$ & $\begin{array}{l}\text { Agri- } \\
\text { culture }\end{array}$ & Labor & $\begin{array}{c}\text { Total } \\
\text { Business }\end{array}$ & Labor & $\begin{array}{c}\text { Total } \\
\text { Business }\end{array}$ & $\begin{array}{l}\text { Anti-Gun } \\
\text { Control }\end{array}$ \\
\hline Contrib 1 & $\begin{array}{l}-.039 \\
(.271)\end{array}$ & $\begin{array}{l}-.048 \\
(.084)\end{array}$ & $\begin{array}{l}-.003 \\
(.003)\end{array}$ & $\begin{array}{l}-.002^{\wedge} \\
(.001)\end{array}$ & $\begin{array}{l}-.002 \\
(.002)\end{array}$ & $\begin{array}{c}.001 \\
(.001)\end{array}$ & $\begin{array}{l}-.151 \\
(.470)\end{array}$ \\
\hline Contrib 1 & NA & -.126 & $.008^{*}$ & .000 & .003 & -.001 & -.360 \\
\hline Moderate & & $(.101)$ & $(.003)$ & $(.002)$ & $(.002)$ & $(.002)$ & $(1.676)$ \\
\hline Contrib 1 & .000 & .137 & .004 & -.001 & .000 & .004 & .305 \\
\hline Competitive & $(.001)$ & $(.116)$ & $(.004)$ & $(.002)$ & $(.003)$ & $(.002)$ & $(.523)$ \\
\hline $\begin{array}{l}\text { Contri- } \\
\text { butions } 2\end{array}$ & Liberal & & Lawyers & & & & \\
\hline Contrib 2 & $\begin{array}{l}.110^{* * *} \\
(.027)\end{array}$ & & $\begin{array}{l}-.003 \\
(.005)\end{array}$ & & & & \\
\hline Contrib 2 & $-.001 *$ & & -.010 & & & & \\
\hline Moderate & $(.000)$ & & $(.012)$ & & & & \\
\hline Contrib 2 & .000 & & -.010 & & & & \\
\hline Competitive & $(.000)$ & & $(.015)$ & & & & \\
\hline Constant & -1.075 & .547 & -.022 & .340 & .299 & .484 & -.885 \\
\hline $\mathrm{R}^{2}$ & .629 & .098 & .424 & .562 & .693 & .338 & .401 \\
\hline $\mathrm{N}$ & 70 & 44 & 73 & 73 & 73 & 73 & 68 \\
\hline
\end{tabular}

Note: Dependent variable is proportion of liberal votes in a given issue area. District average income and contributions are measured in thousands of dollars. Numbers in cells are unstandardized regres- 
APPENDIX (continued)

Table A2 (continued)

\begin{tabular}{|c|c|c|c|c|c|c|}
\hline & Health & Labor & Law & Lottery & Taxes & $\begin{array}{c}\text { Transpor- } \\
\text { tation }\end{array}$ \\
\hline Party & $\begin{array}{l}.307 * * \\
(.107)\end{array}$ & $\begin{array}{l}.537^{* *} \\
(.178)\end{array}$ & $\begin{array}{l}.154 \\
(.221)\end{array}$ & $\begin{array}{l}.385^{* *} \\
(.110)\end{array}$ & $\begin{array}{l}.268^{* *} \\
(.078)\end{array}$ & $\begin{array}{r}.142^{\wedge} \\
(.074)\end{array}$ \\
\hline Ideology & $\begin{array}{c}.074^{\wedge} \\
(.041)\end{array}$ & $\begin{array}{l}-.094 \\
(.068)\end{array}$ & $\begin{array}{l}-.036 \\
(.083)\end{array}$ & $\begin{array}{l}-.041 \\
(.046)\end{array}$ & $\begin{array}{l}.068^{*} \\
(.030)\end{array}$ & $\begin{array}{c}.014 \\
(.028)\end{array}$ \\
\hline$\%$ Black & $\begin{array}{l}.002 \\
(.002)\end{array}$ & $\begin{array}{l}-.001 \\
(.003)\end{array}$ & $\begin{array}{l}.007 \\
(.005)\end{array}$ & $\begin{array}{l}.004 \\
(.002)\end{array}$ & $\begin{array}{l}-.001 \\
(.002)\end{array}$ & $\begin{array}{l}.001 \\
(.001)\end{array}$ \\
\hline$\%$ Farm & $\begin{array}{c}.005 \\
(.014)\end{array}$ & $\begin{array}{l}-.016 \\
(.026)\end{array}$ & $\begin{array}{l}.045 \\
(.030)\end{array}$ & $\begin{array}{l}.016 \\
(.017)\end{array}$ & $\begin{array}{l}-.002 \\
(.011)\end{array}$ & $\begin{array}{l}.014 \\
(.010)\end{array}$ \\
\hline \% Hispanic & $\begin{array}{c}.003 \\
(.003)\end{array}$ & $\begin{array}{l}-.009^{*} \\
(.004)\end{array}$ & $\begin{array}{l}.002 \\
(.006)\end{array}$ & $\begin{array}{l}.004 \\
(.003)\end{array}$ & $\begin{array}{l}-.004^{\wedge} \\
(.002)\end{array}$ & $\begin{array}{l}.001 \\
(.002)\end{array}$ \\
\hline Income & $\begin{array}{l}.000 \\
(.003)\end{array}$ & $\begin{array}{l}-.016^{*} \\
(.004)\end{array}$ & $\begin{array}{l}-.001 \\
(.006)\end{array}$ & $\begin{array}{l}-.001 \\
(.003)\end{array}$ & $\begin{array}{l}-.003 \\
(.002)\end{array}$ & $\begin{array}{l}.002 \\
(.002)\end{array}$ \\
\hline Moderate & $\begin{array}{l}-.130 \\
(.110)\end{array}$ & $\begin{array}{l}.331 \\
(.252)\end{array}$ & $\begin{array}{l}-.607^{\wedge} \\
(.311)\end{array}$ & $\begin{array}{l}.121 \\
(.114)\end{array}$ & $\begin{array}{l}.009 \\
(.095)\end{array}$ & $\begin{array}{l}-.010 \\
(.078)\end{array}$ \\
\hline Competitive & $\begin{array}{l}-.043 \\
(.121)\end{array}$ & $\begin{array}{r}-1.279 * \\
(.516)\end{array}$ & $\begin{array}{l}-.036 \\
(.313)\end{array}$ & $\begin{array}{l}-.120 \\
(.114)\end{array}$ & $\begin{array}{l}-.008 \\
(.103)\end{array}$ & $\begin{array}{l}-.193 * \\
(.078)\end{array}$ \\
\hline $\begin{array}{l}\text { Contri- } \\
\text { butions } 1\end{array}$ & Health & $\begin{array}{c}\text { Total } \\
\text { Business }\end{array}$ & Labor & $\begin{array}{c}\text { Gamb- } \\
\text { ling }\end{array}$ & $\begin{array}{c}\text { Total } \\
\text { Business }\end{array}$ & $\begin{array}{c}\text { Transpor- } \\
\text { tation }\end{array}$ \\
\hline Contrib 1 & $\begin{array}{c}.000 \\
(.004)\end{array}$ & $\begin{array}{l}-.006^{\wedge} \\
(.003)\end{array}$ & $\begin{array}{c}.004 \\
(.013)\end{array}$ & $\begin{array}{l}.055^{* *} \\
(.019)\end{array}$ & $\begin{array}{l}.000 \\
(.001)\end{array}$ & $\begin{array}{l}-.019 * \\
(.009)\end{array}$ \\
\hline Contrib 1 & $.020^{*}$ & -.007 & .023 & -.026 & -.001 & .021 \\
\hline Moderate & $(.009)$ & $(.005)$ & $(.016)$ & $(.046)$ & $(.002)$ & $(.028)$ \\
\hline Contrib 1 & .006 & $.020^{*}$ & .002 & .046 & .001 & .031 \\
\hline Competitive & $(.009)$ & $(.008)$ & $(.018)$ & $(.093)$ & $(.002)$ & $(.023)$ \\
\hline $\begin{array}{l}\text { Contri- } \\
\text { butions } 2\end{array}$ & & Labor & Lawyers & & & \\
\hline Contrib 2 & & $\begin{array}{l}.006 \\
(.009)\end{array}$ & $\begin{array}{l}-.001 \\
(.023)\end{array}$ & & & \\
\hline Contrib 2 & & .002 & .009 & & & \\
\hline Moderate & & $(.010)$ & $(.042)$ & & & \\
\hline Contrib 2 & & .004 & .011 & & & \\
\hline Competitive & & $(.012)$ & $(.059)$ & & & \\
\hline Constant & .054 & 1.410 & .553 & .401 & .398 & .282 \\
\hline $\mathrm{R}^{2}$ & .463 & .588 & .025 & .337 & .487 & .210 \\
\hline $\mathrm{N}$ & 73 & 42 & 43 & 73 & 73 & 73 \\
\hline
\end{tabular}

sion coefficients, standard errors are in parentheses: ***Significant at .001 level,

**Significant at .01 level, *Significant at .05 level, ${ }^{\wedge}$ Significant at .10 level. 
APPENDIX (continued)

Table A3. The Influence of Contributions on Roll Call Votes in Missouri

\begin{tabular}{|c|c|c|c|c|c|c|c|}
\hline & Abortion & $\begin{array}{l}\text { Agri- } \\
\text { culture }\end{array}$ & Crime & $\begin{array}{l}\text { Eco- } \\
\text { nomic }\end{array}$ & $\begin{array}{l}\text { Educa- } \\
\text { tion }\end{array}$ & $\begin{array}{c}\text { Environ- } \\
\text { ment }\end{array}$ & Guns \\
\hline Party & $\begin{array}{c}.019 \\
(.181)\end{array}$ & $\begin{array}{c}.127 \\
(.087)\end{array}$ & $\begin{array}{l}.104^{\wedge} \\
(.059)\end{array}$ & $\begin{array}{l}.272^{* * * *} \\
(.064)\end{array}$ & $\begin{array}{l}.342 * * * \\
(.046)\end{array}$ & $\begin{array}{c}* 342 * * * \\
(.087)\end{array}$ & * $\begin{array}{r}-.071 \\
(.113)\end{array}$ \\
\hline Ideology & $\begin{array}{l}.169 * * \\
(.053)\end{array}$ & $\begin{array}{c}.021 \\
(.025)\end{array}$ & $\begin{array}{l}.078^{* * *} \\
(.018)\end{array}$ & $\begin{array}{c}.045^{*} \\
(.017)\end{array}$ & $\begin{array}{l}.028 * \\
(.014)\end{array}$ & $\begin{array}{l}.033 \\
(.025)\end{array}$ & $\begin{array}{l}.100 * * \\
(.034)\end{array}$ \\
\hline$\%$ Black & $\begin{array}{c}.005^{\wedge} \\
(.003)\end{array}$ & $\begin{array}{c}.001 \\
(.002)\end{array}$ & $\begin{array}{l}-.001 \\
(.001)\end{array}$ & $\begin{array}{l}-.001 \\
(.001)\end{array}$ & $\begin{array}{l}.000 \\
(.001)\end{array}$ & $\begin{array}{l}.000 \\
(.002)\end{array}$ & $\begin{array}{l}.011 * * * \\
(.002)\end{array}$ \\
\hline$\%$ Farm & $\begin{array}{l}.014 \\
(.013)\end{array}$ & $\begin{array}{l}-.007 \\
(.007)\end{array}$ & $\begin{array}{l}-.004 \\
(.006)\end{array}$ & $\begin{array}{l}-.006 \\
(.006)\end{array}$ & $\begin{array}{l}.000 \\
(.005)\end{array}$ & $\begin{array}{l}.003 \\
(.008)\end{array}$ & $\begin{array}{l}.034^{* *} \\
(.012)\end{array}$ \\
\hline$\%$ Hispanic & $\begin{array}{l}.021 \\
(.069)\end{array}$ & $\begin{array}{c}.024 \\
(.041)\end{array}$ & $\begin{array}{l}.014 \\
(.031)\end{array}$ & $\begin{array}{l}-.003 \\
(.030)\end{array}$ & $\begin{array}{l}.003 \\
(.025)\end{array}$ & $\begin{array}{l}.007 \\
(.040)\end{array}$ & $\begin{array}{l}.157^{*} \\
(.062)\end{array}$ \\
\hline Income & $\begin{array}{l}.001 \\
(.006)\end{array}$ & $\begin{array}{l}-.001 \\
(.003)\end{array}$ & $\begin{array}{l}.003 \\
(.002\end{array}$ & $\begin{array}{l}.003 \\
(.002)\end{array}$ & $\begin{array}{l}.005 * * \\
(.002)\end{array}$ & $\begin{array}{l}.002 \\
(.003)\end{array}$ & $\begin{array}{l}.013^{* *} \\
(.005)\end{array}$ \\
\hline Moderate & $\begin{array}{l}-.112 \\
(.120)\end{array}$ & $\begin{array}{l}.067 \\
(.071)\end{array}$ & $\begin{array}{l}-.005 \\
(.064)\end{array}$ & $\begin{array}{l}-.043 \\
(.070)\end{array}$ & $\begin{array}{l}.021 \\
(.043)\end{array}$ & $\begin{array}{l}.065 \\
(.093)\end{array}$ & $\begin{array}{l}.033 \\
(.086)\end{array}$ \\
\hline Competitive & $\begin{array}{l}-.206 \\
(.124)\end{array}$ & $\begin{array}{l}-.003 \\
(.077)\end{array}$ & $\begin{array}{l}.013 \\
(.054)\end{array}$ & $\begin{array}{l}-.113^{\wedge} \\
(.057)\end{array}$ & $\begin{array}{c}.001 \\
(.039)\end{array}$ & $\begin{array}{l}-.029 \\
(.076)\end{array}$ & $\begin{array}{l}-.088 \\
(.084)\end{array}$ \\
\hline $\begin{array}{l}\text { Contri- } \\
\text { butions } 1\end{array}$ & $\begin{array}{l}\text { Conser- } \\
\text { vative }\end{array}$ & $\begin{array}{l}\text { Agri- } \\
\text { culture }\end{array}$ & Labor & $\begin{array}{c}\text { Total } \\
\text { Business }\end{array}$ & Labor & $\begin{array}{c}\text { Total } \\
\text { Business }\end{array}$ & $\begin{array}{l}\text { Anti-Gun } \\
\text { Control }\end{array}$ \\
\hline Contrib 1 & $\begin{array}{l}-.131 \\
(.629)\end{array}$ & $\begin{array}{l}-.033 \\
(.020)\end{array}$ & $\begin{array}{c}.002 \\
(.011)\end{array}$ & $\begin{array}{l}-.003^{\wedge} \\
(.001)\end{array}$ & $\begin{array}{c}.002 \\
(.006)\end{array}$ & $\begin{array}{l}-.001 \\
(.002)\end{array}$ & $\begin{array}{l}.076 \\
(.580)\end{array}$ \\
\hline $\begin{array}{l}\text { Contrib } 1 \\
\text { Moderate }\end{array}$ & NA & $\begin{array}{l}-.046 \\
(.036)\end{array}$ & $\begin{array}{l}.019 \\
(.016)\end{array}$ & $\begin{array}{l}.001 \\
(.003)\end{array}$ & $\begin{array}{l}-.003 \\
(.010)\end{array}$ & $\begin{array}{l}-.003 \\
(.004)\end{array}$ & NA \\
\hline $\begin{array}{l}\text { Contrib } 1 \\
\text { Competitive }\end{array}$ & $\begin{array}{l}.001 \\
(.001)\end{array}$ & $\begin{array}{l}.029 \\
(.036)\end{array}$ & $\begin{array}{l}-.007 \\
(.015)\end{array}$ & $\begin{array}{l}.005^{*} \\
(.002)\end{array}$ & $\begin{array}{l}-.002 \\
(.010)\end{array}$ & $\begin{array}{l}.000 \\
(.003)\end{array}$ & NA \\
\hline $\begin{array}{l}\text { Contri- } \\
\text { butions } 2\end{array}$ & Liberal & & Lawyers & & & $\begin{array}{c}\text { Environ- } \\
\text { ment }\end{array}$ & \\
\hline Contrib 2 & $\begin{array}{l}.160 \\
(.457)\end{array}$ & & $\begin{array}{l}-.012^{\wedge} \\
(.007)\end{array}$ & & & $\begin{array}{l}-1.606 \\
(1.975)\end{array}$ & \\
\hline Contrib 2 & $.001^{\wedge}$ & & -.026 & & & NA & \\
\hline $\begin{array}{l}\text { Moderate } \\
\text { Contrib } 2\end{array}$ & $\begin{array}{l}(.001) \\
-.001\end{array}$ & & $\begin{array}{l}(.019) \\
.004\end{array}$ & & & NA & \\
\hline Competitive & $(.001)$ & & $(.008)$ & & & & \\
\hline Constant & -.460 & .544 & .311 & .418 & .284 & .371 & -.826 \\
\hline $\mathrm{R}^{2}$ & .557 & .296 & .541 & .649 & .761 & .570 & .452 \\
\hline $\mathrm{N}$ & 62 & 76 & 76 & 76 & 76 & 76 & 76 \\
\hline
\end{tabular}

Note: Dependent variable is proportion of liberal votes in a given issue area. District average income and contributions are measured in thousands of dollars. Numbers in cells are unstandardized regres- 
APPENDIX (continued)

Table A3 (continued)

\begin{tabular}{|c|c|c|c|c|c|c|c|}
\hline & Health & Labor & Law & Lottery & $\begin{array}{l}\text { Pen- } \\
\text { sions }\end{array}$ & Taxes & $\begin{array}{c}\text { Transpor- } \\
\text { tation }\end{array}$ \\
\hline Party & $\begin{array}{l}.441 * * * \\
(.045)\end{array}$ & $\begin{array}{l}.335^{* *} \\
(.122)\end{array}$ & $\begin{array}{l}.395 * * * \\
(.057)\end{array}$ & $\begin{array}{l}.516^{* * * *} \\
(.085)\end{array}$ & $\begin{array}{l}.380 * * * \\
(.083)\end{array}$ & $\begin{array}{c}.196 * * \\
(.061)\end{array}$ & $\begin{array}{l}.223 * * \\
(.069)\end{array}$ \\
\hline Ideology & $\begin{array}{l}.020 \\
(.013)\end{array}$ & $\begin{array}{l}.042 \\
(.034)\end{array}$ & $\begin{array}{l}.023 \\
(.017)\end{array}$ & $\begin{array}{l}.049^{\wedge} \\
(.027)\end{array}$ & $\begin{array}{l}.011 \\
(.025)\end{array}$ & $\begin{array}{l}.014 \\
(.016)\end{array}$ & $\begin{array}{l}.067^{* * *} \\
(.019)\end{array}$ \\
\hline$\%$ Black & $\begin{array}{l}.001 \\
(.001)\end{array}$ & $\begin{array}{l}-.001 \\
(.002)\end{array}$ & $\begin{array}{l}.000 \\
(.001)\end{array}$ & $\begin{array}{l}.000 \\
(.002)\end{array}$ & $\begin{array}{l}.000 \\
(.002)\end{array}$ & $\begin{array}{l}.000 \\
(.001)\end{array}$ & $\begin{array}{l}.000 \\
(.001)\end{array}$ \\
\hline$\%$ Farm & $\begin{array}{l}.007^{\wedge} \\
(.004)\end{array}$ & $\begin{array}{l}-.025 \\
(.012)\end{array}$ & $\begin{array}{l}.006 \\
(.006)\end{array}$ & $\begin{array}{l}-.006 \\
(.009)\end{array}$ & $\begin{array}{l}.002 \\
(.008)\end{array}$ & $\begin{array}{l}-.006 \\
(.006)\end{array}$ & $\begin{array}{l}-.005 \\
(.006)\end{array}$ \\
\hline \% Hispanic & $\begin{array}{l}.004 \\
(.021)\end{array}$ & $\begin{array}{l}-.013 \\
(.057)\end{array}$ & $\begin{array}{l}.030 \\
(.030)\end{array}$ & $\begin{array}{l}-.002 \\
(.047)\end{array}$ & $\begin{array}{l}.009 \\
(.045)\end{array}$ & $\begin{array}{l}-.005 \\
(.028)\end{array}$ & $\begin{array}{l}-.44 \\
(.031)\end{array}$ \\
\hline Income & $\begin{array}{l}.006 \\
(.002)\end{array}$ & $\begin{array}{l}.000 \\
(.004)\end{array}$ & $\begin{array}{l}.004^{\wedge} \\
(.002)\end{array}$ & $\begin{array}{l}.007^{\wedge} \\
(.004)\end{array}$ & $\begin{array}{l}.000 \\
(.003)\end{array}$ & $\begin{array}{l}-.001 \\
(.002)\end{array}$ & $\begin{array}{c}.004 \\
(.002)\end{array}$ \\
\hline Moderate & $\begin{array}{l}-.071^{\wedge} \\
(.042)\end{array}$ & $\begin{array}{l}.171 \\
(.140)\end{array}$ & $\begin{array}{l}.024 \\
(.061)\end{array}$ & $\begin{array}{l}.066 \\
(.072)\end{array}$ & $\begin{array}{l}.013 \\
(.078)\end{array}$ & $\begin{array}{l}.081 \\
(.066)\end{array}$ & $\begin{array}{l}.064 \\
(.068)\end{array}$ \\
\hline Competitive & $\begin{array}{l}-.063 \\
(.040)\end{array}$ & $\begin{array}{l}-.101 \\
(.120)\end{array}$ & $\begin{array}{l}-.031 \\
(.052)\end{array}$ & $\begin{array}{c}.046 \\
(.064)\end{array}$ & $\begin{array}{l}-.082 \\
(.070)\end{array}$ & $\begin{array}{l}.017 \\
(.054)\end{array}$ & $\begin{array}{l}.033 \\
(.061)\end{array}$ \\
\hline $\begin{array}{l}\text { Contri- } \\
\text { butions } 1\end{array}$ & Health & $\begin{array}{c}\text { Total } \\
\text { Business }\end{array}$ & Labor & $\begin{array}{c}\text { Gamb- } \\
\text { ling }\end{array}$ & Labor & $\begin{array}{c}\text { Total } \\
\text { Business }\end{array}$ & $\begin{array}{l}\text { Transpor- } \\
\text { tation }\end{array}$ \\
\hline Contrib 1 & $\begin{array}{l}.004 \\
(.004)\end{array}$ & $\begin{array}{l}-.008^{* *} \\
(.003)\end{array}$ & $\begin{array}{l}-.016 \\
(.010)\end{array}$ & $\begin{array}{c}.005 \\
(.037)\end{array}$ & $\begin{array}{l}.002 \\
(.011)\end{array}$ & $\begin{array}{l}-.002^{\wedge} \\
(.001)\end{array}$ & $\begin{array}{l}.024 \\
(.024)\end{array}$ \\
\hline Contrib 1 & $.008^{\wedge}$ & -.005 & .013 & -.118 & -.011 & -.002 & -.010 \\
\hline $\begin{array}{l}\text { Moderate } \\
\text { Contrib } 1\end{array}$ & $\begin{array}{c}(.005) \\
.002\end{array}$ & $\begin{array}{r}(.005) \\
.008^{*}\end{array}$ & $\begin{array}{c}(.017) \\
.017\end{array}$ & $\begin{array}{l}(.329) \\
-.180\end{array}$ & $\begin{array}{c}(.018) \\
.013\end{array}$ & $\begin{array}{c}(.003) \\
.002\end{array}$ & $\begin{array}{l}(.026) \\
-.018\end{array}$ \\
\hline Competitive & $(.005)$ & $(.004)$ & $(.014)$ & $(.122)$ & $(.018)$ & $(.002)$ & $(.026)$ \\
\hline $\begin{array}{l}\text { Contri- } \\
\text { butions } 2\end{array}$ & Women's & Labor & Lawyers & & & & \\
\hline Contrib 2 & $\begin{array}{c}.169 \\
(.290)\end{array}$ & $\begin{array}{c}.010 \\
(.015)\end{array}$ & $\begin{array}{c}.004 \\
(.006)\end{array}$ & & & & \\
\hline Contrib 2 & -.210 & -.011 & -.030 & & & & \\
\hline Moderate & $(.346)$ & $(.023)$ & $(.018)$ & & & & \\
\hline Contrib 2 & -.543 & .000 & .001 & & & & \\
\hline Competitive & $(1.064)$ & $(.023)$ & $(.008)$ & & & & \\
\hline Constant & .376 & .095 & .377 & -.016 & .259 & .198 & .373 \\
\hline $\mathrm{R}^{2}$ & .793 & .829 & .743 & .088 & .292 & .776 & .646 \\
\hline $\mathrm{N}$ & 53 & 53 & 53 & 53 & 53 & 53 & 53 \\
\hline
\end{tabular}

sion coefficients, standard errors are in parentheses: ***Significant at .001 level, **Significant at .01 level, *Significant at .05 level, ${ }^{\wedge}$ Significant at .10 level. 


\section{NOTES}

${ }^{1}$ To be more specific, most research has focused almost exclusively at roll call voting in the House although some studies do examine contributions and voting in the Senate.

${ }^{2}$ See below for further information about the survey and sample.

${ }^{3}$ The terms interest group and PAC are used interchangeably here, even though they do have different meanings. The intent is to examine what influence groups, PACs and corporations that share a common interest have over roll call voting.

${ }^{4}$ These codes were derived from Congressional Quarterly's categorization of congressional roll call votes with a few modifications, such as the inclusion of lotteries and the exclusion of foreign affairs, to reflect different policy concerns at the state level.

${ }^{5}$ In these legislatures, rules vary about the type of amendments that may be attached to a bill. Given that the text of amendments is widely unavailable for all of these legislatures, there was no way to ascertain whether a given amendment actually fell into the same issue area as the bill to which it was attached. As a result, all votes on amendments and any motions regarding amendments were excluded from this analysis.

${ }^{6}$ As these scores measure the proportion of times a legislator voted liberally in a given issue area, a "liberal" vote had to be identified. This was a more difficult task than it as first seems. Given that many of these bills had a small number of dissenting votes (some had less than 5\%), it was not entirely clear for each bill which side was a liberal vote and which side was a conservative vote. In order to determine whether a yea vote or a nay vote on a given bill was a liberal vote, each vote was correlated with NOMINATE scores generated for these chambers. A high NOMINATE score was coded to mean a tendency to vote liberally. Therefore, any bill that had a negative correlation with NOMINATE scores was recoded so that a yea vote on all bills represents a liberal vote. Each vote was also correlated with party identification and ideology scores in order to verify the NOMINATE correlation. In going through this process, it became clear that for those votes with very little dissent, the correlations were unreliable. For these votes, it was much more likely than with other votes that the correlations with NOMINATE, party, and ideology were not consistent. For example, most votes that had a positive correlation with NOMINATE scores also had positive correlations with party and ideology, meaning that Democrats and liberals were more likely to vote yes on that bill. However, for the low dissent votes, this was not always the case; often, there would be positive correlations with two of the variables and a negative correlation with another variable. As a result, a decision was made to eliminate all bills with less than 10 percent dissent (either less than 10 percent voting yes or less than 10 percent voting no). While this reduced the number of votes available for the analysis, this also increased the reliability of the scores generated. By eliminating these votes, it could be said with much more confidence that these votes did indeed represent liberal votes on these bills.

${ }^{7}$ They also include categories for defense and public subsidies; there were no contributions in these areas in any of these states.

${ }^{8}$ One might argue that a balance of contributions variables (subtracting total conservative contributions from liberal contributions) could be used instead, but Roscoe and Jenkins $(2005,63)$ find that significant relationships are less likely to be found when multiple contribution variables are included, so this conservative approach was used here.

${ }^{9}$ For the state senates, senators who did not stand for election in 1996 were matched to surveys from 1992 or 1994 (whichever year their last election fell in) if they had completed one. 
${ }^{10}$ Overall, the response rates for these legislatures was $44.3 \%$. Individually, the response rates were as follows: $50.8 \%$ in the Colorado House, $57.1 \%$ in the Colorado Senate, $40.7 \%$ in the Illinois House, $50.8 \%$ in the Illinois Senate, $39.9 \%$ in the Missouri House and $41.2 \%$ in the Missouri Senate. Importantly, t-tests indicate these respondents accurately reflected the composition of the legislative body as a whole in terms of partisanship, the demographics of their constituency, their overall voting tendencies and the competitiveness of the past election. Thus, they seem to provide solid footing for drawing conclusions about the nature of legislative behavior in these states.

${ }^{11}$ Logistic regression was also run for the issue areas with 1 vote (CO Abortion votes, and IL Agriculture, Labor Unions and Law votes); these models were run without the demographic variables as the inclusion of these variables created instability in the models due to the small number of cases. Because the substantive results for the contributions described below generally speaking do not differ, the OLS regression results are reported below for the sake of brevity and consistency.

${ }^{12}$ There were four constituency variables in each model; with fourteen models in Missouri and Colorado and thirteen in Illinois, that means there were 164 occurrences of these variables.

${ }^{13}$ According to Brambor et al. (2006, 73), effect sizes for interaction variables can be determined by adding the coefficients. Thus, when the interaction variable has the opposite sign as the main contribution variable, the overall effect in these cases will be smaller or in the opposite direction.

\section{REFERENCES}

Baumgartner, Frank R., and Bryan D. Jones. 1993. Agendas and Instability in American Politics. Chicago: University of Chicago Press.

Brace, Paul, and John A. Staayer. 1987. Colorado: PACs, Political Candidates, and Conservatism. In Interest Group Politics in the American West, eds. Ronald J. Hrebenar and Clive S. Thomas. Salt Lake City: University of Utah Press.

Brambor, Thomas, William Roberts Clark, and Matt Golder. 2006. Understanding Interaction Models: Improving Empirical Analyses. Political Analysis 14:63-82.

Center for Public Integrity. 1999 (February 19). Hidden Agendas: How State Legislators Keep Conflicts of Interest Under Wraps. http://www.publicintegrity.org/oi/ report.aspx?aid=617\#1999rank. Retrieved August 13, 2007.

Center for Public Integrity. 2006 (April 26). In Your State. http://www.publicintegrity. org/iys/. Retrieved August 13, 2007.

Cronin, Thomas E., and Robert D. Loevy. 1993. Colorado Politics and Government: Governing the Centennial State. Lincoln: University of Nebraska Press.

Dow, Jay K., and James W. Endersby. 1994. Campaign Contributions and Legislative Voting in the California Assembly. American Politics Quarterly 22:334-353.

Everson, David H., and Samuel K. Gove. 1993. Illinois: Political Microcosm of the Nation. In Interest Group Politics in the Midwestern States, eds. Ronald J Hrebenar and Clive S. Thomas. Ames: Iowa State University Press.

Fleisher, Richard. 1993. PAC Contributions and Congressional Voting on National Defense. Legislative Studies Quarterly 18:391-409.

Hersch, Philip L., and Gerald S. McDougall. 1988. Voting for 'Sin' In Kansas. Public Choice 57:127-139. 
Jennings, M. Kent, and Harmon Zeigler. 1970. The Salience of American State Politics. American Political Science Review 64:523-535.

Joens, David A., and Paul Kleppner. 1998. Almanac of Illinois Politics-1998. Springfield, IL: Institute for Public Affairs.

Kingdon, John W. 1984. Agendas, Alternatives, and Public Policy. Boston, MA: Little, Brown.

Langbein, Laura I., and Mark A. Lotwis. 1990. The Political Efficacy of Lobbying and Money: Gun Control in the U.S. House, 1986. Legislative Studies Quarterly 15: 413-440.

Moncrief, Gary F. 1998. Candidate Spending in State Legislative Races. In Campaign Finance in State Legislative Elections, eds. Joel A. Thompson and Gary F. Moncrief. Washington, DC: Congressional Quarterly Press.

Morehouse, Sarah McCally. 1981. State Politics, Parties and Policy. New York: Holt, Rinehart, and Winston.

Neustadtl, Alan. 1990. Interest-Group PACsmanship: An Analysis of Campaign Contributions, Issue Visibility and Legislative Impact. Social Forces 69:549-564.

Nownes, Anthony J., Clive S. Thomas, and Ronald J. Hrebenar. 2008. Interest Groups in the States. In Politics in the American States, 9th ed., eds. Virginia Gray and Russell Hanson. Washington, DC: CQ Press.

Patterson, Samuel C. 1991. State Legislators and the Legislatures. In Politics in the American States, 5th ed., eds. Virginia Gray, Herbert Jacob, and Robert B. Albritton, USA: HarperCollins Publishers.

Quinn, Dennis P., and Robert Y. Shapiro. 1991. Business Political Power: The Case of Taxation. American Political Science Review 85:851-874.

Redfield, David. 1998. What Keeps the Four Tops on Top? Leadership Power in the Illinois General Assembly. Pp. 1-8 in Almanac of Illinois Politics-1998, eds. David A. Joens and Paul Kleppner. Springfield, IL: Institute for Public Affairs.

Roscoe, Douglas D., and Shannon Jenkins. 2005. A Meta-Analysis of Campaign Contributions' Impact on Roll Call Voting. Social Science Quarterly 86:52-68.

Saltzman, Gregory M. 1987. Congressional Voting on Labor Issues: The Role of PACs. Industrial and Labor Relations Review 40:163-179.

Schecter, David L., and David M. Hedge. 2001. Dancing with the One who Brought You: The Allocation and Impact of Party Giving to State Legislators. Legislative Studies Quarterly 26:437-456.

Smith, Richard A. 1995. Interest Group Influence in the U.S. Congress. Legislative Studies Quarterly 20:89-139.

Squire, Peverill, and Keith E. Hamm. 2005. 101 Chambers: Congress, State Legislatures, and the Future of Legislative Studies. Columbus: The Ohio State University Press.

Stratmann, Thomas. 1991. What Do Campaign Contributions Buy? Deciphering Causal Effect of Money and Votes. Southern Economic Journal 57:606-620.

Thomas, Clive S., and Ronald J. Hrebenar. 1996. Interest Groups in the States. In Politics in the American States: A Comparative Analysis, eds. Virginia Gray and Herbert Jacob. Washington, DC: CQ Press.

Valentine, David. 1995. The Missouri General Assembly. Pp. 105-124 in Missouri Government and Politics, eds. Richard J. Hardy, Richard R. Dohm, and David A. Leuthold. Columbia: University of Missouri Press.

Welch, William P. 1982. Campaign Contributions and Legislative Voting: Milk Money and Dairy Price Supports. Western Political Quarterly 35:478-495. 


\section{8 | Shannon Jenkins}

Wiggins, Charles W., Keith E. Hamm, and Charles G. Bell. 1992. Interest-Group and Party Influence in the Legislative Process: A Comparative State Analysis. Journal of Politics 54:82-100.

Wilhite, Allen, and John Thielman. 1987. Labor PAC Contributions and Labor Legislation: A Simultaneous Logit Approach. Public Choice 53:267-276.

Wright, John R. 1996. Interest Groups and Congress. Boston: Allyn \& Bacon. 